\title{
Publicidade institucional e marca organizacional: caso EDP Renováveis
}

Renata Suely de Freitas* e Teresa Ruão**

Resumo: Este trabalho pretende investigar de que forma a publicidade institucional pode associar valores à marca organizacional. Sabe-se que as imagens e os textos publicitários não só informam sobre o produto ou o serviço; os discursos publicitários transmitem ideias e sentimentos que podem ser relacionados à marca e incentivar o desejo e a simpatia pelo anunciante. Desse modo, como pode a publicidade ajudar a construir uma imagem favorável da marca junto ao público? Para entender esses processos de significação, as primeiras partes do trabalho farão uma exposição sobre as teorias em torno da publicidade institucional e dos significados conotativos que podem envolver a comunicação publicitária. Para enriquecer a pesquisa, apresentaremos um estudo de caso envolvendo uma campanha publicitária da EDP Renováveis, que em 2009 ganhou o prêmio de Melhor Publicidade Institucional pela Associação Portuguesa de Comunicação de Empresa (APCE).

Palavras-chave: publicidade institucional, marcas, significados.

\section{Introdução}

A publicidade convive com os consumidores, informando os produtos, incentivando a compra, incitando os desejos, nas ruas, nos meios de comunicação social, na caixa de correio, na caixa de e-mails. O receptor da mensagem publicitária recebe um conjunto de imagem e texto em que é possível perceber significados associados ao produto, serviço ou ideia. Mas de que maneira a publicidade institucional transmite valores associados à marca? A partir dessa questão de partida, o presente trabalho tem como objetivo debater conceitos e pensamentos em torno da publicidade institucional e dos processos de

\footnotetext{
* Doutoranda em Ciências da Comunicação - Universidade do Minho (renatadefreitas@gmail.com).

** Instituto de Ciências Sociais da Universidade do Minho, Centro de Estudos de Comunicação e Sociedade (truao@ics. uminho.pt).
} 
significação na publicidade. Desse modo, organizaremos pistas para analisar mensagens publicitárias de marcas organizacionais, o que faremos a partir de um estudo de caso.

Para construir um quadro de referência teórico, pretende-se discutir as características da comunicação publicitária e quais seus desafios perante a sociedade contemporânea, marcada por manifestos publicitários carregados de força e promovedores de construção de sentidos. Para perceber qual é a capacidade da publicidade em influenciar ideias, vamos discutir as técnicas e os objetivos da comunicação publicitária. Também podemos problematizar se, ao enaltecer as características do enunciador, a publicidade não só visa chamar a atenção do público, mas pretende também transferir valores para a marca.

A estrutura deste trabalho partirá das definições sobre publicidade, em especial sobre publicidade institucional ${ }^{1}$, e sua importância para a comunicação organizacional ${ }^{2}$. Nesse sentido, será necessária uma breve explicação sobre a relação entre a publicidade, as marcas organizacionais e o processo de construção da imagem nas organizações.

Segundo Corral (1997: 17), “a publicidade é uma prática significante que requer um espaço semiótico, onde se situa sujeito enunciador e enunciatário”, e para analisar essa prática significante escolhemos como estudo de caso uma campanha de publicidade da EDP Renováveis, organização líder mundial do segmento de energias renováveis. Uma fase dessa campanha publicitária ganhou o prêmio de Melhor Publicidade Institucional de 2009 oferecido pela Associação Portuguesa de Comunicação de Empresa (APCE). Pretende-se, por fim, contribuir com resultados interpretativos acerca da publicidade com objetivo de propagar a marca organizacional e acerca das técnicas usadas para atingir este fim.

\section{A publicidade na sociedade contemporânea}

Desde sempre as imagens fazem parte da história humana, como afirma Joly (1996: 59): "instrumento de comunicação entre as pessoas, a imagem pode também servir de instrumento de intersecção entre o homem e o próprio mundo". Muito do que sabemos sobre os primeiros grupos e as primeiras sociedades é por meio de imagens deixadas, vestígios e desenhos de outra época, pintadas ou talhadas. As figuras encontradas informam sobre as primeiras relações sociais do homem. Por meio de representações gravadas, deu-se origem aos primeiros alfabetos, e pôde-se acumular conhecimentos para além da memorização oral, ajudando a transmitir crenças, culturas, mitos, medos, enfim, histórias de uma geração para outra.

Atualmente, há muitas imagens que interagem com os cidadãos, imagens visuais, imagens mentais, imagens virtuais. Usa-se imagens para observação prática: tira-se ima-

\footnotetext{
${ }^{1}$ Publicidade institucional é o termo usado nas referências bibliográficas portuguesas utilizadas neste trabalho. Cabe esclarecer que outros países com Língua Portuguesa utilizam o termo "propaganda institucional" como sinônimo, como é o caso dos autores brasileiros.

2 A denominação comunicação "organizacional" oscila entre os termos "empresarial", "institucional", "corporativa", conforme o enfoque do autor e a linha de investigação seguida. Para este trabalho, optamos por seguir a teoria que se estruturou no campo disciplinar da "Comunicação Organizacional", mas por vezes fala-se no termo "empresa" por conta do estudo de caso sobre uma empresa portuguesa.
} 
gens do corpo humano para diagnósticos, tira-se imagens do planeta para conceber seu tamanho. Mas também se pode falar de construção de imagens no plano de representações mentais: estuda-se a imagem do imigrante, a imagem da mulher, constrói-se a imagem de uma organização no mercado, a imagem de um político em campanha eleitoral. Muitas imagens interagem com as pessoas através dos meios de comunicação, são as imagens midiáticas, que ainda podem levar a construções de novas imagens na percepção de cada pessoa, imagens essas relacionadas com a representação psíquica.

Com o avanço da tecnologia, novos tipos de imagens entram no cotidiano social, imagens de computadores, imagens em três dimensões para cinema, imagens interativas, imagens com efeitos especiais na publicidade. Para Joly (1996: 69), a própria publicidade é o "protótipo" da imagem midiática. Por meio da publicidade, recebe-se signos denotativos que levam a imagens conotativas através de interpretações.

Explicar "publicidade" é difícil, uma vez que existem ideias preconcebidas sobre o tema. Muitas vezes confundida com marketing, propaganda, relações públicas, assessoria de imprensa, entre outras áreas que envolvem a comunicação, a publicidade tenta manter sua posição de investimento necessário para a concretização da marca organizacional no mercado.

Se há muitas definições a serem vistas em torno do conceito de publicidade, conduziremos esta primeira parte do texto para definir o que é publicidade, e como essa prática está inserida no contexto da comunicação organizacional. Assim, esclareceremos a diferença entre identidade e imagem de marca, para, por fim, discutir os objetivos da publicidade institucional de marca. Segundo Rasquilha (2009: 20), a publicidade é a:

técnica de comunicação de massas, destinada a um público específico e que é especialmente paga e utilizada com o objetivo de dar a conhecer e valorizar uma Marca (produto, serviço ou instituição), contribuindo para a sua experimentação, consumo, adesão, fidelização, utilização ou apoio.

Para já, é preciso esclarecer que, mesmo sendo um conceito relacionado à comunicação de massa, os avanços tecnológicos têm permitido inúmeras possibilidades de meios personalizados, de modo que a publicidade já atua ao nível pessoal, ou focada em pequenos nichos de públicos. A sociedade contemporânea tem reinventado os modos de utilizar a publicidade, tanto que agora o público é capaz de editar e compartilhar conteúdos publicitários.

De volta ao conceito descrito acerca de publicidade, entende-se que a comunicação publicitária ajuda a vender, podendo influenciar na escolha de um produto pelos valores atribuídos para a marca. E aqui falamos em "vender" e "comprar" não só no sentido literal de adquirir um produto, mas também no sentido metafórico de vender ou comprar uma ideia sobre uma marca ou sobre um comportamento social.

Há uma tendência, principalmente no campo profissional, em explicar o objetivo publicitário de organizar ações para que o público tenha uma ideia completa e satisfatória sobre o produto a partir da teoria do marketing. Isso porque os primeiros estudos sobre publicidade, assim como os primeiros estudos da comunicação organizacional, 
tiveram espaço nas disciplinas de Sociologia, de Gestão e de Marketing. Não pretendemos pensar a publicidade apenas como uma ferramenta, da maneira que o marketing elabora, e sim como um processo comunicativo capaz de transmitir significados sobre a organização e interferir nas tendências sociais. No entanto, como o marketing é importante para explicar a natureza estratégica da publicidade, cabe dizer que, segundo Kotler (2000: 29), marketing "é toda atividade humana dirigida para a busca da satisfação das necessidades e dos desejos dos consumidores”.

Para situar em que área se instalaria a publicidade em uma organização orientada para o marketing, como muitas organizações do fim do século XX se estruturaram, temos que saber que o marketing organiza as suas atividades segundo variáveis para administrar a organização e interagir com o mercado e os envolvidos na cadeia: produto, preço, promoção (comunicação), praça (distribuição) ${ }^{3}$. A publicidade está inserida dentro do "P" Promoção, e como este é um termo com significado limitado tem se substituído pelo próprio termo Comunicação.

Sugere-se que as atividades de publicidade, propaganda, relações públicas, assessoria de imprensa e outras afins, possam trabalhar integradas para conseguir posicionar a marca da organização e transmitir uma imagem satisfatória ao público e ao mercado em geral. Muitas vezes, o sucesso da marca não é mensurado pelo número de vendas do produto, e sim pela posição que a marca ocupa na mente das pessoas, que gera poder simbólico para a marca. Da mesma forma, não se pretende apenas cativar o público que consome o produto, pretende-se gerar boa impressão para os stakeholders, que são todos os envolvidos na cadeia entre o produto e o consumidor: desde produtores, distribuidores, fornecedores, sócios, concorrentes e instituições da sociedade, como o governo. Uma marca de visão também não esquece os futuros consumidores e os nichos de mercado latentes.

Para o conceito em torno de publicidade ficar completo, ainda é preciso uma breve definição sobre marcas. Segundo Aaker (1998), a marca é um nome ou um símbolo personalizado que identifica produtos ou serviços de um produtor para o mercado consumidor e concorrente. Pinho (2006) completa a definição lembrando que a marca não representa somente um produto, serviço ou organização, a marca associa valores e propriedades intangíveis que ajudam a diferenciá-la no mercado e na mente dos consumidores.

Para Rasquilha (2009: 26), “a marca é o valor intangível, o ativo que representa um potencial de vendas e que dá lucro à empresa, criando o seu território de imagem, suporte dos negócios e base das estratégias de comunicação". Com essas definições, podemos indicar que a publicidade da marca, como meio de comunicação, pode ajudar no processo de construção do conhecimento da organização e na formação da percepção de qualidade pelo consumidor. Ao atribuir mais valores para a comunicação, tenta-se que a marca figure entre as preferidas na mente dos consumidores.

Para ser coerente com a marca organizacional, é sugerível que a publicidade siga a identidade organizacional e o manual visual da organização, que engloba todas as

\footnotetext{
${ }^{3}$ Os conceitos do marketing têm se atualizado constantemente e já foram propostos novos "P".
} 
características visuais e de inter-relação da organização com seus stakeholders, como embalagens, fachadas de lojas, transportes de distribuição, uniformes de funcionários, recepção de pós-venda, entre outros (Aaker \& Joachimsthaler, 2000). Esse conjunto transmite uma imagem sobre a organização que interage com a percepção do público interno e externo.

As indicações supracitadas sobre identidade e imagem de uma organização têm significados diferentes. Segundo Ruão (2006), a identidade nasce dentro da organização, é um conjunto de características percebidas por quem faz a organização produzir. A identidade responde, em termos simbólicos, quem a organização é, de acordo com a sua missão. Já a imagem é a representação mental que os indivíduos têm da organização, é o conjunto de características que as pessoas e os grupos associam à organização ou à marca. Por isso, há a imagem projetada, que a organização pretende que o público tenha, baseada na sua identidade, e há a imagem percebida, resultado de informações, sentimentos, percepções, enfim, de experiências do público com a organização.

Desse modo, a imagem organizacional é uma "representação psicossociológica de determinada realidade" (Rasquilha, 2009: 191). Muitos quesitos influenciam a imagem de uma organização, como a motivação das pessoas envolvidas no trabalho, o ambiente e suas instalações, os materiais gráficos e até a logomarca publicada. Além disso, há fatores psicossociológicos como o tratamento de funcionários e públicos diversos, suas condições de trabalho e outros pontos que envolvem as políticas de comunicação interna. Ainda há um fator decisivo na imagem da organização: a qualidade do produto ou do serviço que se oferece.

Assim, quando a organização e seus funcionários trabalham para que a imagem seja positiva, e quando a publicidade é coerente com essa imagem, é possível criar uma impressão de uniformidade quanto à imagem institucional, e ajudar na afirmação da marca no mercado e no imaginário do consumidor. Como Rasquilha (2009: 191) afirma:

A imagem desejada por uma empresa deve igualmente coincidir com a imagem interna percebida pelos seus empregados e gestores (potenciais líderes de opinião dentro da empresa), e com a imagem externa percebida pelos outros públicos. A imagem que se aproxima do público externo é o espelho da identidade corporativa.

E então, como pode a identidade da marca ser transmitida para o público por meio da publicidade? É para reunir informações que ajudem a entender esse processo que conduziremos o trabalho para o estudo da publicidade institucional. Todo processo de comunicação da organização com seu exterior e interior faz parte da sua comunicação institucional. Como ramo da comunicação, a publicidade também se presta a esse fim institucional e, como é uma técnica comunicativa, pode levar as características da organização ao conhecimento do público. 


\section{Publicidade Institucional}

Já foi citado que nos referimos neste trabalho à publicidade da marca organizacional, mas é preciso clarificar que a publicidade de marca pode ter objetivos comerciais como vender um produto, ou fins institucionais, que consistem em "vender" (metaforicamente) um conceito sobre a organização. Para Volli (2003: 132), a publicidade institucional "não visa o ato do consumo; pelo contrário, os seus conteúdos comunicativos servem para valorizar, em termos gerais, a empresa produtora como realidade empírica". O objeto de valorização na publicidade institucional é o emissor, a organização, a marca; e não o produto. O conteúdo a ser vendido é a identidade da organização - e por isso torna-se interessante demonstrar competência, ética e missão atrativa.

Como foi exposto, o discurso publicitário pode tentar incitar o desejo e persuadir à ação, mas também pode tentar agregar características positivas ao enunciador, de modo que o receptor da mensagem oriente seu comportamento favoravelmente à marca. A publicidade é provocadora de ações de pensamentos e de atividades, depois de estabelecer associações mentais entre a marca e a mente do consumidor (Volli, 2003). A fim de que a informação a ser passada seja atrativa, a publicidade estuda o modo como a mensagem deve ser produzida para surtir mais efeito. O produto ou o serviço ou a ideia podem ser consumidos por simpatia, por satisfazerem as necessidades do indivíduo, ou porque são atribuídos valores emocionais para os objetivos sociais de consumo (Rasquilha, 2009).

Viu-se até aqui que uma imagem coordenada com a identidade da organização tem importância para projetar uma unidade organizacional e levar ao público quais são os valores da marca e as suas vantagens frente aos concorrentes. Então, a publicidade auxilia no processo de reconhecimento de marca, sendo que a própria comunicação de marca "representa um universo simbólico e imaginário" (Rasquilha, 2009: 28).

Com a globalização e os avanços tecnológicos, um evento que tem sido notável no mercado é a formação de multinacionais. Com os acordos entre mercados internacionais, muitas organizações expandiram para outros países e juntaram-se a outras organizações para ter mais força. Com a matriz em um país, mas atuação em diversos centros, as atividades comunicacionais das organizações tiveram que se adaptar. Do ponto de vista publicitário, surgiu nas últimas décadas o conceito de publicidade global. O conceito de comunicação publicitária global projeta marcas globais para diversos locais, alcançando mercados novos e públicos diferentes. Para que a imagem promovida pela organização seja global, é preciso aplicar técnicas integradas de cultura interna e imagem externa, como explica Rasquilha (2009: 41): "a comunicação global através do território de marca gera um sistema de valores e de referência. No panorama atual da comunicação, cada vez mais as estruturas integradas são uma realidade".

No caso da publicidade global, há a necessidade de estandardizar campanhas que permitam adaptações a sociedades locais. Podemos citar como exemplos de organizações com comunicação de marca global: Coca-Cola, Vodafone, Sony, McDonalds, Canon, cigarros, bebidas alcoólicas, entre outras. Apesar de a publicidade global ser realizada por marcas universais, a comunicação global pode ser feita por qualquer marca, a não ser que o diferencial da organização seja a regionalização. As vantagens da publici- 
dade global são custos de produção similares, com adaptações para a distribuição. No entanto, há desvantagens como hábitos culturais diferentes entre os países, que resultam em diferentes expectativas de consumo entre o público (Aaker \& Joachimsthaler, 2000).

Reunido este quadro teórico em torno da publicidade, voltamos aos questionamentos iniciais do trabalho: de que forma se constroem sentidos para a marca por meio da publicidade? Como pode a identidade da marca ser transmitida para o público por meio de imagens e textos publicitários?

Segundo Volli (2003), uma das pistas é que o discurso publicitário auxilia a impor um valor semiótico à compra. Como a publicidade é significativa, pode comunicar algo a mais do que sua presença descreve. A mensagem presente na publicidade pode descrever os benefícios racionais e emocionais da aquisição do produto, pode associar valores à marca, como também pode transmitir um modo de ser que o consumidor almeja para si.

Para que nossa interpretação sobre a comunicação publicitária fique mais enriquecida, para além do pragmatismo da sua teoria, conduziremos a discussões mais filosóficas para compreender alguns dos processos de significação nas imagens e textos publicitários envolvendo as marcas organizacionais.

\section{Processos de significação da publicidade}

Já que queremos contribuir com interpretações no plano abstrato da significação publicitária, sugerimos desconstruir o processo enunciativo, que distribui mensagens com incitações linguísticas para despertar vontades no consumidor e orientar comportamentos. Porque, conforme Volli (2003), a compra não é apenas uma atividade econômica, é também uma atividade semiótica. Pode-se dizer que a compra tem uma carga de significados, uma construção de sentidos, principalmente quando se compra roupa, acessórios, veículos, para que outras pessoas vejam e admirem, e essa atividade se torne representação de status.

A teoria de análise de processos de significados implícitos na publicidade envolve alguns estudos da semiótica. Segundo Santaella (2002), a semiótica estuda linguagens que produzem significados e sentidos. Entre os estudos mais clássicos de semiótica estão as teorias de Pierce que envolvem o signo, seu objeto e sua interpretação; e os estudos de Saussure mais relacionados à linguística e à semiologia. Volli (2003) lembra de estudiosos que contribuíram para a análise da comunicação publicitária: Barthes, com influências de Saussure, foi um dos primeiros a analisar a publicidade como objeto semiológico, e Durand (1974) publicou sobre a retórica da publicidade, analisando mais de mil peças publicitárias e classificando conotações implícitas nas mensagens.

Na publicidade, segundo Corral (1997), o sujeito semiótico tem que ter competência interpretativa sobre o leitor, de modo que haja um contrato enunciativo entre o remetente e o destinatário da mensagem publicitária. A imagem que o emissor constrói do receptor orienta a produção publicitária, assim como a imagem que o remetente constrói sobre si mesmo é importante para que o destinatário acredite e confie na mensagem. O emissor da mensagem estuda o mercado, o público e a concorrência para "introduzir linguisticamente no texto as antecipações das representações do receptor, sobre as que 
elabora os objetivos e estratégias da comunicação" (Corral, 1997: 19). Mas sabe-se que nem sempre foi assim; antigamente, o discurso publicitário se limitava a descrever os produtos comerciais, pelo seu valor de uso ou de troca. Hoje em dia, Corral (1997: 24) explica que a publicidade "se converte ela mesma no objeto de consumo: a descrição da utilidade do produto é reemplacada por sua descrição afetiva e imaginária”.

Mesmo assim, podemos dizer que a publicidade não tem toda responsabilidade sobre organizar consumos, mas sim, em estimular desejos e sonhos. Para algo tornar-se costume é preciso que o consumidor, dotado de dinheiro, cultura interpretativa, estímulo social, entre outros requisitos, complete o ato de adquirir o produto ou a ideia. Também é importante lembrar que o receptor da mensagem não é passivo, ele interage com a mensagem, podendo ser mais ou menos convencido pelo discurso. Os desejos e as necessidades estimuladas tentam responder, em parte, a aspirações que o consumidor realmente sente. A assessoria de psicólogos é cada vez mais comum no mercado de agências publicitárias, para vender o produto pelo que ele pode significar para o público, mais do que pelas suas características físicas (Corral, 1997).

Nesse sentido, a publicidade pode falar da simulação de realidade, e não apenas sobre a realidade em si. Um exemplo disso é uma das estratégias clássicas para construção de texto publicitário, que consiste em simular uma situação inicial de carência: o destinatário, antes da mensagem, “carece”. Nessa composição, o publicitário parte de um enunciado (realidade ou simulacro) onde o consumidor teria faltas ou necessidades que seriam solucionadas pelo produto anunciado. Então, o sujeito que tem desejo pelo objeto fica satisfeito ao adquirir a mercadoria e os valores simbólicos atribuídos. A possibilidade de simular situações onde há carência é possível, pois a publicidade

cria um espaço e um tempo artificiais, narrativos, nos quais pode propor-se como uma imagem fiel da realidade, fornecendo "informações sobre o produto", assim como pode contar histórias e contos fantásticos, ou simplesmente "criar impressões" sensoriais ou psicológicas sobre o seu valor. (Volli, 2003: 18)

Com o objetivo de convencer ou mudar o sistema de orientação do consumidor sobre aquele assunto, Volli (2003: 30) cita a "posição parasitária" do texto publicitário, pois conduz o receptor a condições de fora, situações que pertencem ao mundo exterior da narração. Volli (2003: 108-109) também expõe as formas narrativas possíveis na comunicação publicitária: contrato-sanção, quando o produto se compromete a exercer uma performance e o cliente está na função de destinatário; narrativa em forma de competência, quando não só é mostrada a função do produto, como também é mostrada a competência da marca como diferencial; e por fim, a forma de sanção pura, quando se expõe a satisfação do consumidor, sendo uma espécie de sanção imediata, antes mesmo da utilização do produto.

Há muitos textos publicitários que contam histórias, pois a narrativa pode gerar sentidos. Todavia, apesar de o uso de narrações ser comum, lembramos que a dimensão sígnica tem sua autonomia sem a utilização de narrativa no caso de logomarcas. Se pensarmos em marcas como Nike, Mercedes, Gilette, entre outras, é possível conduzir 
a processos de significação sem precisar de um texto ao lado, apenas com a logomarca ou com a imagem do produto.

A teoria da criação do texto publicitário afirma que para melhor compreender uma mensagem é preciso saber para quem essa mensagem foi produzida. Conhecer o público-alvo da publicidade é saber se expressar de modo que o mesmo preste atenção. Relembramos que os cidadãos respondem a estímulos, não são passivos, compram o produto ou a ideia se tiverem condições (interpretativas e financeiras) para fazer essa ação. Ademais, é preciso ter em mente o contexto, o modo de contato e o código que leva o destinador a passar a mensagem para o destinatário. Para Joly (1996: 75): “além da mensagem literal ou denotada, evidenciada pela descrição, existe uma mensagem 'simbólica' ou conotada, vinculada ao saber preexistente e compartilhado do anunciante e do leitor".

Sobre denotações e conotações, Volli (2003) explica, com base em Barthes, que o signo denotativo é o primeiro apresentado à mente, depois é relacionado a um segundo signo (aquilo que o signo denotativo se refere) e, por fim, faz-se relação com um terceiro signo interpretado pelo consumidor. A fase de significação passa pelas características sensoriais percebidas, depois pelos detalhes da mensagem no seu contexto, para por fim chegarmos à interpretação geral e cultural da mensagem.

No caso da publicidade institucional, aliar à marca valores através da imagem e do texto é providencial para que o público perceba a personalidade da organização. Ao falar de imagem de marca, faz-se referência a processos mentais resultantes de identificações e representações processadas pelos indivíduos e grupos; não se faz relação imediata com objetos a sua semelhança. Joly (1996: 84) explica que "as imagens não são as coisas que representam, elas se servem das coisas para falar de outra coisa”, o que nos faz questionar os significados que podem ser acrescentados a uma peça publicitária para que agregue valores às marcas.

\section{Estudo de caso: EDP Renováveis}

A fim de reunir pistas sobre como os processos de significação conduzem a interpretações positivas associadas à marca, será conduzido um estudo de caso sobre a publicidade da organização EDP Renováveis. O método de estudo de caso investiga a fundo fenômenos específicos, sendo um "modelo de análise intensiva de uma situação particular" (Correia \& Pardal, 1995: 23). Este método é muitas vezes escolhido para explicar um fenômeno que existe dentro de um contexto organizacional. No estudo de caso, pode-se escolher uma variedade de técnicas, a depender dos resultados esperados. Nossas análises serão feitas a partir das indicações de Volli (2003), Corral (1997), Joly (1996), nos seus estudos sobre a publicidade, discurso e imagem.

Tendo a publicidade institucional como foco, escolhemos para analisar a campanha ganhadora do Prêmio Comunicação Institucional 2009 da APCE (Associação

\footnotetext{
${ }^{4}$ A "Gala do Grande Prémio APCE 2009 - Excelência em Comunicação" premiou em 25 de Maio de 2009 vinte categorias, entre elas: Campanha de Comunicação Institucional, Campanha de Comunicação de Responsabilidade Social, Ação de
} 
Figura 1

Fase I da campanha publicitária da EDP Renováveis, com o nome "Ciclo de Vida", que circulou em Portugal de 30 de Abril a 18 de Maio de 2009. Fonte: www.edprenovaveis.com
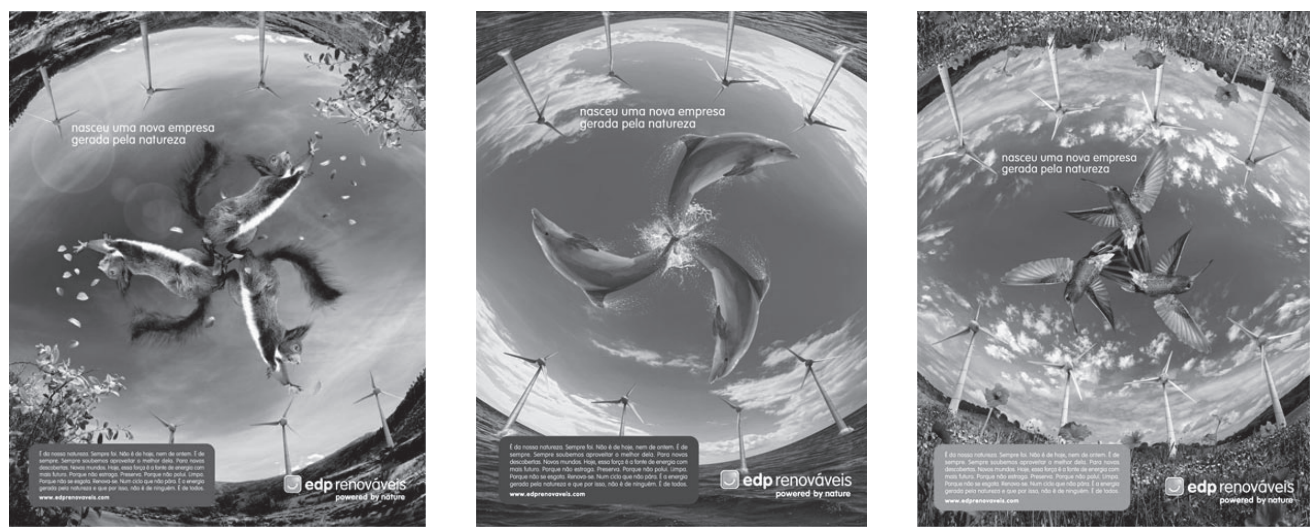

Portuguesa de Comunicação de Empresa). A APCE, associação sem fins lucrativos, promove desde 1990 discussões relacionadas com comunicação nas organizações, envolvendo profissionais da área, estudantes e empresas, em Portugal, na Europa e no espaço da lusofonia. No quesito Campanha de Comunicação Institucional, a EDP Renováveis, organização líder mundial do segmento de energias renováveis, foi ganhadora e parte do Grupo EDP, o maior grupo de indústrias de Portugal.

A publicidade campeã faz parte de um conjunto de três fases integradas da EDP Renováveis que circularam em Portugal no primeiro semestre de 2009. A fase I da campanha publicitária, que ganhou o prêmio, foi intitulada "Ciclo da Vida" e circulou de 30 de Abril a 18 de Maio de 2009 na imprensa. A publicidade institucional compôs-se de três peças com fotos (Figura 1), e título e caixa de texto, que seguem

Nasceu uma nova empresa gerada pela natureza

É da nossa natureza. Sempre foi. Não é de hoje, nem de ontem. É de sempre. Sempre soubemos aproveitar o melhor dela. Para novas descobertas. Novos mundos. Hoje, essa força é a fonte de energia com mais futuro. Porque não estraga.

Preserva. Porque não polui. Limpa. Porque não se esgota. Renova-se. Num ciclo que não pára. É a energia gerada pela natureza e que, por isso, não é de ninguém. É de todos.

A literal descrição dos anúncios é uma imagem com animais, flores, plantas, mar e aerogeradores circulando pelas peças. Entretanto, o modo como esses signos foram compostos traz sentidos a mais para a publicidade. As três peças têm muitos elementos, mas

Formação, Responsabilidade Histórica e Memória Empresarial, Relatório de Gestão, Relatório de Sustentabilidade, Webletter, Website e Hotsite, Blogue, Vídeo e Webcast. As categorias e os vencedores estão disponíveis no site http://www.apce.pt/noticias/lernoticia.php?idN=48Cr54567:86223485346883853.

${ }^{5}$ Imagens e textos disponíveis em www.edprenovaveis.com/pt/index.asp? $\mathrm{MP}=44 \& \mathrm{MS}=482 \& \mathrm{MN}=3$. 
que estão em comum, gerando uma unidade visual, a ponto de que o consumidor possa identificá-las como parte de uma campanha. No centro das imagens há animais: esquilos, golfinhos e pássaros, dispostos em três, de maneira que lembrem a forma de um cata-vento de três pontas, ou seja, a forma de um aerogerador. Ao redor, em torno do círculo, há figuras de aerogeradores e outros elementos da natureza. Nota-se que a ideia é integrar a marca EDP Renováveis aos elementos naturais, pois a energia eólica advém da força do vento, fazendo referência clara a uma distribuição de energia advinda da natureza.

O texto apresentado é curto, com frases fragmentadas, o que, segundo Joly (1996: 112), "contamina um postulado com outro, transferindo as qualidades sazonais e temporais do primeiro para o segundo, provocando desse modo uma associação". A assinatura da EDP Renováveis no canto inferior direito segue a linha de orientação de leitura de imagem.

A marca EDP já é conhecida pelo consumidor português, o acréscimo da palavra “Renováveis" vem informar para qual fim se destina essa marca. Para Pinho (1996: 18), se o nome da marca for descritivo, seu poder de comunicação com o consumidor é maior, tal como a possibilidade de o destinatário da mensagem assimilar a marca com mais facilidade. A aposta da organização no slogan "powered by nature", na língua inglesa corresponde à tentativa de marca universal, de uma organização global, para se comunicar com públicos de sociedades diferentes. A logomarca é apresentada na cor verde, que é a cor principal da natureza.

Por questões de espaço, nossa amostra se restringe às peças apresentadas em revistas da imprensa portuguesa, mas cabe relatar que as outras ações dessa campanha englobaram outdoors, spots e multimídia. Os outdoors continham as mesmas imagens, mas sem caixa de texto, apenas com os títulos, como a limitação de um meio de comunicação exterior exige para ser compreendida de maneira mais rápida por mais pessoas.

Para percebermos a diferença entre a publicidade institucional, que transmite valores associados à identidade da marca, e a publicidade comercial, que atrai à compra do produto/serviço, passaremos para a segunda parte da campanha da EDP Renováveis.

A “fase II - Poder", que veiculou de 19 a 26 Maio de 2009, dá ênfase ao fato que a EDP Renováveis está entre as quatro maiores empresas do mundo em energias 100\% limpas e convida os interessados para serem acionistas da organização. As imagens estão na Figura 2 (p. seguinte). Como se pode perceber, o texto mostra a vantagem e depois convida o consumidor a ter o poder junto:

Quantas empresas podem dizer que estão entre as 4 maiores do mundo em energias $100 \%$ limpas? A EDP Renováveis pode. E quantas pessoas podem hoje investir na nossa natureza? Você pode. Contacte já o seu banco e invista na energia da natureza. Até 26 de Maio, subscreva acções da EDP Renováveis e beneficie de condições preferenciais de rateio no segmento do público em geral. Atribuição prioritária para accionistas da EDP.

Em termos de comunicação estratégica, essas peças publicitárias continuam o raciocínio da primeira fase da campanha: cores verdes e azuis, um círculo com aerogeradores e no centro uma disposição que lembra a forma de cata-vento do aerogerador. Dessa 


\section{Figura 2}

Fase Il da campanha publicitária da EDP Renováveis, intitulada "Poder", que veiculou em Portugal de 19 a 26 de Maio de 2009. Fonte: www.edprenovaveis.com.


vez, os personagens ao centro são pessoas: jovem masculino com bicicleta, jovem feminina praticando kitesurf e homem de negócios com jornal. A interação de pessoas com o meio ambiente, por meio da bicicleta, do kitesurf, do cotidiano profissional, enfatiza o relacionamento da natureza com a marca e os seus consumidores.

As cores predominantes na publicidade são verde e azul, e não são por acaso, pois provocam associações interpretativas: são as cores do Planeta Terra. Para Farina (1990), as cores relacionadas à publicidade estimulam reações no corpo e na mente; e a cor verde não evoca apenas tranquilidade, mas também virilidade, coragem e desejo. O Planeta Terra também pode ser visto da perspectiva do círculo que contém no interior os animais. O título dentro do círculo sugere que o nascimento da empresa vem da natureza.

Outras pistas de significação podem ser adicionadas: os golfinhos e os pássaros (da primeira fase da campanha) e a bicicleta e o kitesurf (da segunda fase) são personagens e características que no imaginário social revelam a ideia de liberdade. Essas "cadeias conotativas", como afirma Volli (2003: 87-88), conduzem a valorizações:

um signo que, no seu todo, tem por significante uma certa organização de linhas e de cores e por significado uma pomba torna-se (graças à sua colocação sintagmática na história bíblica de Noé) significante de um novo signo, cujo significado é a paz.

Nas narrações, a semiótica identifica o anunciado e a enunciação - o que é prometido e as circunstâncias e características do que é dito. Ao analisar os textos que a publicidade exibe, vê-se que os verbos são conjugados por vezes na primeira pessoa do plural, por vezes no modo imperativo. As frases curtas almejam que o leitor, provavelmente cidadão saturado de mensagens no seu cotidiano, leia fragmentadamente e assimile mais fácil o conceito. Pretende-se incitar a mudança com as "novas descober- 
tas, novos mundos”. Os verbos preservar, limpar, renovar têm energia, quer-se motivar o consumidor a aceitar que aquela atividade é benéfica e importante. O final "é de todos" indica um sentimento de coletividade, para que o consumidor se sinta pertencente àquela ideia.

Assim, percebe-se a manipulação dos signos e das estruturas narrativas da publicidade para que sejam construídas formas de buscar a adesão do receptor, o que Corral (1997) chama de objetivo pragmático da publicidade. Volli (2003: 30) afirma que "a ação publicitária pede sempre qualquer coisa ao leitor, apresenta por ele um custo de uma ação, de uma mudança de atitude cognitiva ou sentimental”.

Quando o texto da fase II cita "quantas empresas podem dizer que estão entre as 4 maiores do mundo em energias 100\% limpas? A EDP Renováveis pode”, é colocada a marca em posição única, posição de destaque, mostrando um diferencial da marca. Volli (2003) defende, com base em Saussure, um valor opositivo de sentido na semiótica da publicidade. Ou seja, acredita que, apesar de os discursos publicitários acrescentarem sentidos aos produtos, sua intenção principal é “opor produtos e marcas semelhantes, instituir diferenças onde materialmente nem existam, construir posições” (Volli, 2003: 50-51). Desse modo, o valor opositivo citado seria concorrencial, no sentido de criar diferenciais para o produto, distanciá-los do concorrente, abrir um "nicho" na mente do consumidor de que aquela marca é especial. Acreditamos que a publicidade pode, ela própria, ser um caráter de diferenciação para o produto oferecido, em dias que as ofertas, os canais de distribuição e os investimentos são tão similares entre os concorrentes.

Por fim, a terceira parte da campanha foi a "fase III - Countdown", que apenas recordou que a subscrição de ações terminaria a 30 de Maio de 2009. O texto é o mesmo da segunda fase da campanha, mas desta vez há um rapaz a formar os três eixos da energia eólica. A imagem pode ser conferida na Figura 3. A roupa de explorador, aventureiro, não é por acaso: cria-se um personagem corajoso que faça com que o consumidor queira estar no lugar.

Essa disposição estratégica dos signos promove valorizações utópicas, com sentidos sociais. Outros tipos de valorizações poderiam ser: valorização prática, segundo a utilidade do objeto; valorização lúdica, conforme a capacidade de atrair e divertir o público; ou

Figura 3

Fase III da campanha publicitária da EDP Renováveis, chamada "Countdown". Fonte: www.edprenovaveis.com.

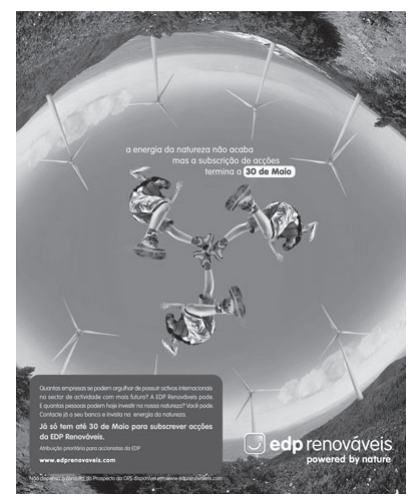


valorização crítica, por conveniência econômica (Volli, 2003). Nota-se que a valorização utópica adequa-se melhor ao objetivo institucional da publicidade que se está a analisar.

Podemos interpretar essas imagens publicitárias, segundo Joly (1996: 65), analisando eixos plásticos como formas, cores, composição e textura. As formas que predominam nas imagens são a forma de cata-vento, de modo que mostre a integração do aerogerador à natureza (com animais na fase I) e com o ser humano (por meio das pessoas nas fases II e III). A composição dos elementos gráficos forma um círculo, um espaço vazio ao meio, que transmite a ideia de liberdade. As cores, como já foram citadas, foram escolhidas por serem as cores da natureza, são cores fortes que chamam a atenção. Ainda é possível perceber que ao colocar os animais e as pessoas em forma de cata-vento quebrou-se a forma dura e seca que o aerogerador tem. Ou seja, humanizou-se o equipamento. Os pequenos aereogeradores ao redor da imagem estão dispostos em forma de flores sob a relva, sensibilizando a sua presença.

Como foi citado no capítulo anterior, para unir valor a uma marca, um signo denotativo é relacionado a um significante (como por exemplo, palavras ou grafismo), que gera um significado 1 (um objeto). Esse signo conotativo, que é o significante 2 (o signo denotativo); gera um significado 2 (um valor). Por fim, o signo publicitário, relacionado ao significante 3 (o signo conotativo), gera um significado 3: a marca (Volli, 2003). No caso da publicidade que estamos analisando, podemos concluir que os animais dispostos em três significam o aerogerador; esse aerogerador significa energia limpa e natural, renovação de força, futuro; por fim, esses valores são relacionados à marca EDP Renováveis. Quem deseja consumir essa ideia gosta de apoiar o conceito de energia renovável e acredita na força advinda da natureza, de modo limpo.

É possível perceber que a publicidade institucional, que enfatiza a marca organizacional (aqui exemplificado com a primeira fase da campanha), tem objetivo de relacionar a marca EDP Renováveis ao ambiente da natureza, e por isso foram usados animais como personagens. Joly (1996: 53) lembra que "tanto a presença quanto a ausência de um elemento resultam de uma escolha que a análise deverá tomar em consideração, tanto quanto é possível". Como as fases II e III da campanha têm o objetivo de levar o consumidor à ação da compra, foram usadas pessoas nas imagens.

A abordagem semiótica da imagem permite estudar a publicidade visual a partir de suas significações, não apenas por meio de presenças estéticas. Na campanha da publicidade da EDP Renováveis apresentada, a fotografia das pessoas (que é o significante) representa adultos divertindo-se (que podemos chamar de referente) e leva o receptor da mensagem a interpretar realização profissional ao comprar as ações (por fim, o significado) (Volli, 2003; Joly, 1996).

\section{Apontamentos finais}

Reuniu-se nesse trabalho um conjunto de teorias sobre a publicidade institucional e os processos de significação da publicidade. A compreensão sobre a publicidade institucional procedeu ao entendimento de marcas, de identidade e de imagem organizacional. Viu-se até aqui que as marcas utilizam a comunicação para publicitar sua existência 
organizacional. Os produtos industriais são “marcados” para entrar no mercado, sendo a própria marca a primeira definição de diferenciação.

A abordagem semiótica da publicidade auxiliou a reflexão sobre as possíveis associações mentais entre marca e consumidor por meio da comunicação publicitária. Percebeu-se que a organização dos signos, de forma estratégica, integrando imagem e texto, produz efeitos interpretativos e pode associar valores à marca anunciante. No estudo de caso apresentado sobre a publicidade da EDP Renováveis, viu-se que a construção de significados se deu pela interação de diferentes signos denotativos e conotativos entre a natureza, o homem e a marca.

Podemos elaborar algumas indicações sobre o processo de transmissão da identidade organizacional para o público por meio da publicidade através de formas conotativas que, no caso da EDP Renováveis, integraram a marca ao ambiente da natureza e da energia renovadora. Os textos, estratégicos e persuasivos, indicaram uma marca organizacional forte e líder mundial, ao ponto que suscitasse no consumidor o desejo de se associar à causa e aos investimentos oferecidos.

Quanto à imagem, conclui-se que os signos visuais da publicidade indicaram a mensagem plástica: anúncio de uma página inteira de revista, com fotografias retiradas da realidade natural, reorganizadas de maneira que possibilitassem associações. Já os signos icônicos ou figurativos puderam ser interpretados por meio de conotações, como a disposição das pessoas em forma de aerogerador. Cabe lembrar que essas interpretações icônicas dependem da experiência do receptor da mensagem e da sua capacidade associativa (Joly, 1996).

Salienta-se que a publicidade tende a figurativizar o destinatário, pois o receptor da mensagem se reconhece em um personagem, e o mais comum é que o personagem, mais bonito e rico que o real, esteja satisfeito com o produto. Ou seja, o personagem criado não retrata fielmente o público-alvo, retrata a imagem idealizada que o público quer, e que a marca pode ajudar a consagrar. A possibilidade que o receptor tem de se sentir no lugar do personagem evoca intimidade, associa a marca a valores positivos e produz maior eficácia da narração persuasiva.

Quanto ao texto, conclui-se que a diagramação estava a favor do plano de orientação da leitura gráfica e os discursos apresentados atribuíam valores de força para a marca. Os textos indicavam distinção, e nas últimas peças analisadas, os textos incitavam o desejo de compra. Como completa Volli (2003: 91), a narração do texto publicitário “constrói um mundo possível em que os valores em questão são partilhados, praticados, distribuídos”.

Ao integrar a teoria apresentada com os resultados do estudo de caso, percebe-se que as últimas fases da campanha publicitária da EDP Renováveis, fase II e fase III, tiveram objetivo comercial de venda do produto, incitando o desejo de compra. Com outra intenção, a fase I teve objetivo de marcar a empresa no mercado e no imaginário do público, mostrando valores relacionados à personalidade da marca, que é onde se situa nosso principal exemplo de publicidade institucional.

Por meio da publicidade institucional, a marca EDP Renováveis pôde exprimir sua identidade comunicativa, força e autonomia. É isso que se espera da publicidade insti- 
tucional, que ajude no processo de afirmação da marca organizacional, para que alcance uma densidade semântica. No entanto, sabe-se que a publicidade sozinha não faz milagres. É imprescindível que a organização empregue seu valor identitário em todos bens e serviços que produz, de modo que haja continuidade na imagem da sua marca.

A identidade organizacional é melhor difundida se reproduzida no ambiente de produção e venda dos produtos ou serviços oferecidos, e no comportamento das pessoas dentro da organização. A imagem transmitida, de igual maneira, é influenciada por essas atividades, pois todas elas difundem percepções sobre a organização. Para Pinho (2006: 29), a identidade organizacional "diferencia a empresa de modo positivo e memorável, projetando assim uma personalidade única e posicionando adequadamente a companhia no mercado".

No estudo de caso apresentado também se notou a preocupação com a comunicação global. Tem-se o slogan em inglês, por exemplo, mesmo sendo uma organização de origem portuguesa. O conceito de marca global só é possível na sociedade contemporânea, que permite que o mesmo produto tenha acesso a sociedades diferentes. No caso da publicidade global, é preciso ter preocupação com valores universais e com valores particulares da sociedade em questão.

Por mais que não seja possível fazer, de imediato e sem um estudo aprofundado, uma relação direta entre a campanha publicitária da EDP Renováveis de 2009 e seu crescimento econômico como organização, o website da marca expõe que em 2010 registrou-se um crescimento excepcional, tendo a EDP Renováveis um lucro líquido de mais de $10 \%$ em relação a 2008 e mais de $25 \%$ em relação a 2009 .

Ainda cabe relatar que, para a comunicação chegar ao receptor, não basta apenas divulgar, pois o público recebe muitos estímulos publicitários todos os dias. A necessidade de saber o que o público gosta e quais seus hábitos e costumes é importante para que a publicidade atinja seu consumidor. A publicidade será interpretada, e esse processo depende dos conceitos prévios adquiridos pelo receptor da mensagem.

Por fim, notou-se que a campanha publicitária analisada da EDP Renováveis foi direcionada para um público-alvo que se interessa em preservar os elementos da natureza. Nas fases em que havia objetivo de incitar à compra, a publicidade aponta para um público que também se preocupa com seu progresso financeiro, a ponto de investir seu patrimônio em ações da organização. Estudos futuros, no âmbito dos processos de identidade e de imagem de marca, poderão investigar como a marca organizacional projeta sua identidade em todas suas atividades e nas técnicas de comunicação integrada. Também será interessante avaliar, por pesquisa quantitativa e qualitativa, como o público-alvo da organização interpreta a imagem recebida por diversos meios de comunicação.

\section{Referências bibliográficas}

Aaker, D. (1998) Managing Brand Equity, New York: Simon \& Schuster. Aaker, D. \& Joachimsthaler, E. (2000) Brand leadership, USA: Free Press.

Corral, L. S. (1997) Semiótica de la Publicidad - Narración y discurso, Madrid: Editorial Sintesis.

Correia, E. \& Pardal, L. (1995) Métodos e Técnicas de Investigação Social, Porto: Areal. 
Durand, J. (1974) 'Retórica e Imagem Publicitária' in: Metz, C. et alii. Análise das Imagens, Petrópolis: Vozes. Farina, M. (1990) Psicodinâmica das Cores em Comunicação, São Paulo: Edgard Blucher.

Joly, M. (1996) Introdução à Análise da Imagem, Campinas: Papirus.

Kotler, P. (2000) Administração de Marketing, São Paulo: Prentice Hall.

Pinho, J. B. (1996) O Poder das Marcas, São Paulo: Summus Editorial.

Rasquilha, L. (2009) Publicidade, Lisboa: Gestão Plus.

Ruão, T. (2006) Marcas e Identidades, Porto: Campo das Letras.

Santaella, L. (2002) O que é Semiótica?, São Paulo: Editora Brasiliense.

Volli, U. (2003) Semiótica da Publicidade - A criação do texto publicitário, Lisboa: Edições 70.

Website Associação Portuguesa de Comunicação de Empresa (APCE). Disponível em http://www.apce.pt. Acesso em 19 de Dezembro de 2009.

Website EDP Renováveis. Disponível em www.edprenovaveis.com. Acesso em 22 de Dezembro de 2009. 